\title{
Parameters of the Immune System and Vitamin D Levels in Old Individuals
}

\author{
Amanda Soares Alves ${ }^{1}$, Mayari Eika Ishimura ${ }^{1}$, Yeda Aparecida de Oliveira Duarte ${ }^{2}$ and \\ Valquiria Bueno ${ }^{1 *}$
}

${ }^{1}$ Division of Immunology, DMIP Microbiology, Immunology, and Parasitology, Federal University of São Paulo, São Paulo, Brazil, ' 2 ivision of Epidemiology, Faculdade de Saúde Pública, Universidade de São Paulo, São Paulo, Brazil

\section{OPEN ACCESS}

Edited by:

Lorraine M. Sordillo, Michigan State University, United States

Reviewed by:

Jean M. Fletcher, Trinity College, Dublin, Ireland Antonio Paolo Beltrami, University of Udine, Italy

*Correspondence: Valquiria Bueno vbueno@unifesp.br

Specialty section: This article was submitted to Nutritional Immunology, a section of the journal Frontiers in Immunology

Received: 14 December 2017 Accepted: 03 May 2018 Published: 24 May 2018

Citation:

Alves AS, Ishimura ME, Duarte YAdO and Bueno V (2018) Parameters of the Immune System and Vitamin D Levels in Old Individuals. Front. Immunol. 9:1122. doi: 10.3389/fimmu.2018.01122
Aim: The increased number of individuals older than 80 years, centenarians, and supercentenarians is not a synonym for healthy aging, since severe infections, hospitalization, and disability are frequently observed. In this context, a possible strategy is to preserve the main characteristics/functions of the immune system with the aim to cause less damage to the organism during the aging process. Vitamin $D$ acts on bone marrow, brain, breast, malignant cells, and immune system and has been recommended as a supplement. We aimed to evaluate whether immune parameters and vitamin D serum levels are correlated.

Methods: We evaluated some features of the immune system using the peripheral blood of individuals older than 80 years $(n=12)$ compared to young subjects $(n=10)$. In addition, we correlated these findings with vitamin $\mathrm{D}$ serum levels.

Results: Old individuals presented metabolic parameters of healthy aging and maintained preserved some features of immunity such as CD4/CD8 ratio, and low production of pro-inflammatory cytokines after stimulus. On the other hand, we observed increase in the frequency of myeloid-derived suppressor cells, reduction in circulating leukocytes, in the percentage of total CD8+, and in CD8+ Naiive T cells, in addition to increase in the percentage of CD8+ effector memory re-expressing CD45RA (EMRA) T cells. We found seropositivity for CMV in 97.7\%, which was correlated with the decrease of CD8+ Naiive T cells and increase in CD8+ EMRA T cells. Vitamin D levels were insufficient in $50 \%$ of old individuals and correlated positively with total CD8+ T cells and negatively with CD8+ EMRA T cells.

Conclusion: In the studied population, longevity was correlated to maintenance of some immune parameters. Considering the limitations of the study as size of the sample and lack of functional assays, it was found that vitamin D in old individuals was correlated to some features of the immune system, mainly in the CD8 compartment.

Keywords: longevity, immunity, vitamin D, myeloid-derived suppressor cells, T cells

\section{INTRODUCTION}

In several developed and developing countries, human longevity has been achieved (1-3) but insufficient function of the immune system in the old population leads to severe infections, frequent hospitalizations, and immunization reduced after vaccination (4-6).

Therefore, to reach the longevity with good quality of life, a possible strategy is to preserve the main characteristics/functions of the immune system with the aim to cause less damage to the organism 
during the aging process. Aging has been associated with lower generation of progenitors from pluripotent hematopoietic stem cells (HSC) located in the bone marrow. In addition, there occurs a myeloid-biased differentiation of HSC due to selection pressures from cell-intrinsic and extrinsic mechanisms (7-10). These factors lead to a decrease in the number of circulating leukocytes and increased frequency in the myeloid lineage. The increase in the frequency of myeloid cells may be the reason for the recently described increase in myeloid-derived suppressor cells (MDSC) in aging individuals. MDSC membrane markers are $\mathrm{CD}_{11 \mathrm{~b}^{+}}$ $\mathrm{CD}_{3}{ }^{+} \mathrm{HLA}^{-} \mathrm{DR}^{-/ \text {low }}$, which can be subtyped in monocytic MDSC $\left(\mathrm{CD} 14^{+}\right)$or granulocytic $\left(\mathrm{CD} 15^{+}\right) \mathrm{MDSC}$.

The suppressive actions of MDSC are mainly based on the production of arginase-1, reactive oxygen species, nitric oxide (NO), IL-10, and TGF- $\beta 1$. These cells exert several effects on lymphocytes such as impairment in the antigen presentation and recognition by $\mathrm{T}$ cells, deficient $\mathrm{B}$ and $\mathrm{T}$ cells activation, and accumulation of regulatory $\mathrm{T}$ cells $(11,12)$.

Changes in hematopoiesis have also been related to the decreased percentage of $\mathrm{CD} 4^{+}$and $\mathrm{CD}^{+} \mathrm{T}$ cells in the circulating blood. In addition, the inverted CD4/CD8 ratio was reported by Swedish OCTO and NONA immune longitudinal studies as a blood marker predictive for a high rate of mortality in 2,4 , and 6 years (immune risk profile) (13).

Another aspect of aging is the thymic involution which has been linked to less diversity in the T-cell receptor and decreased frequency of Naive T cells $(14,15)$, while the peripheral homeostatic proliferation compensates for the T-cell loss $(16,17)$.

The phenotype of $\mathrm{T}$ cells has been used to characterize the immune system status and Hamann et al. $(18,19)$ proposed that in humans, the $\mathrm{CD}^{+} \mathrm{T}$ cell compartment presents four different phenotypes based on membrane markers and cellular function. The phenotype $\mathrm{CD}_{4} 5 \mathrm{RA}^{+} \mathrm{CD} 27^{+}$represents undifferentiated Naive cells and CD45RA ${ }^{-} \mathrm{CD} 27^{+}$lymphocytes are antigenexperienced $\mathrm{T}$ cells (central memory) with increased frequency of lymphotoxicity precursors (CTLp). CD45RA ${ }^{+} \mathrm{CD} 27^{-}$cells present features of antigen-stimulated cells with cytolytic potential, production of IFN- $\gamma$ and tumor necrosis factor-alpha (TNF- $\alpha$ ), high amounts of perforin and granzyme B, Fas ligand mRNA expressed in abundancy, and cells exerting potent cytotoxic activity without previous in vitro stimulation [effector memory re-expressing CD45RA (EMRA)]. CD45RA ${ }^{-} \mathrm{CD} 27^{-} \mathrm{T}$ cells are observed in low frequency and express perforin and granzyme $\mathrm{B}$ (effector memory). The correlation between aging and increased frequency of $\mathrm{CD}^{+} \mathrm{CD}^{2} 5 \mathrm{RA}^{+} \mathrm{CD} 27^{-}$has been reported. The same phenotypes were identified in different stages of $\mathrm{CD}^{+} \mathrm{T}$ cells mainly during stimulation by viral infections (CMV, EBV, HSV, and VZV) $(20,21)$.

In order to preserve the functional characteristics of the immune system that could in turn prevent and/or delay agerelated diseases, health professionals have proposed physical activity, control of diet, supplements, and probiotics (22-24).

The main actions of vitamin $\mathrm{D}$ in bone tissue and the latest reports of its effects on bone marrow, brain, colon, breast, malignant cells, and immune system (25) raised the interest of researchers to investigate the role played by vitamin $\mathrm{D}$ in the immunity of old individuals.
Considering that low levels of vitamin D are common in older individuals, some health professionals have recommended vitamin $\mathrm{D}$ supplementation to the aging population in general and especially for aged-care residents and critically ill patients (26-28). However, the benefits arising on the immunity with vitamin D supplementation are not consistent in the literature. Upper respiratory infections (URI) in non-hospitalized middleaged and older individuals with vitamin D supplementation have been associated with a lower incidence of infection (29), discrete decrease of infections events (30), or no alteration in severity and duration of infection $(31,32)$. In addition, residents of sheltered accommodation supplemented with vitamin $\mathrm{D}$ showed increase in URI and duration of symptoms and no changes to the risk or duration of lower respiratory infections (33). However, in patients with antibody deficiency or increased susceptibility to respiratory tract infections (RTI), supplementation with vitamin D was beneficial and associated with fewer episodes of RTI and increased time for first infection compared to placebo group (34).

As the extension of life expectancy is a reality, it is a challenge to understand how the aging population deals with the remodeling of the immune system and if interventions as vitamin D could provide extra years of life with good health. In this study, our goal was to investigate changes that occur in some parameters of the immune system in individuals reaching longevity ( $80-100$ years) and the possible correlation with vitamin D levels.

\section{MATERIALS AND METHODS}

The present study is part of a larger epidemiologic survey called the health, well-being, and aging study (SABE), which was coordinated by the Pan-American Health Organization, Washington, and in Brazil by the School of Public Health of the University of São Paulo. From 2000 to 2001, SABE evaluated a sample of 2,143 non-institutionalized individuals, representing 836,204 aging people (60 years and older) living in the municipality of São Paulo, who were selected through multi-stage sampling. In 2006, the School of Public Health continued the survey in São Paulo and transformed it into a multi-cohort study with 1,115 individuals from the previous study who agreed to participate in the follow-up. Since then, the survey has been repeated every 5 years. In this study, the inclusion/exclusion criteria were applied as cited above, except that we used blood only from individuals older than 80 years (male, female) and they were enrolled as their biological samples were received. Young individuals (20-30 years, male and female) were master and Ph.D. students from UNIFESP.

The blood samples were collected with $12 \mathrm{~h}$ of fasting (6:00 a.m.-9:00 a.m.) during the summer months (December, January, and February) in Brazil.

The Ethics Committee of the Federal University of São PauloUNIFESP approved all procedures (Protocol number 10904).

Peripheral blood mononuclear cells (PBMCs) were isolated using Ficoll-Hypaque density gradient (Amersham Biosciences, Uppsala, Sweden) and centrifugation. Viable cells were counted, adjusted for $2 \times 10^{6} / 100 \mu \mathrm{L}$ in $80 \%$ fetal bovine serum and $20 \%$ dimethylsulfoxide (Sigma, St. Louis, MO, USA), and frozen stored $\left(-80^{\circ} \mathrm{C}\right)$ until the phenotyping and cell culture. 


\section{Cell Culture}

Cells were diluted in RPMI 10, counted, and adjusted for $1 \times 10^{6} / 100 \mathrm{~mL}$. The assessment of cell proliferation was based on a substance (CFSE) that once in the cell cytoplasm halves its content to each cell division. Cells were incubated with 5(6)carboxyfluorescein acetate (CFSE, CFDA Vybrant IF Cell Tracer Kit Invitrogen) for $10 \mathrm{~min}$. The cells were washed, counted, and adjusted for plating $\left(2 \times 10^{5} / 100 \mu \mathrm{L}\right.$ of RPMI10 per well $)$. Culture conditions were phytohemagglutinin $\left(\mathrm{PHA}^{+}, 5 \mu \mathrm{g} / \mathrm{mL}\right.$, Sigma) or absence of stimulus (PHA) for $72 \mathrm{~h}$ in $5 \% \mathrm{CO}_{2}$, humidity controlled and $37^{\circ} \mathrm{C}$. After 3 days of culture, the cell suspension was collected, centrifuged, and the proliferation (CFSE) was measured in flow cytometer (35). The cell culture supernatant was frozen $\left(-80^{\circ} \mathrm{C}\right)$ for the measurement of cytokines (ELISA).

\section{Cell Phenotype}

The cells were stained with monoclonal antibodies to T-cell phenotype CD3 APC, CD4 PerCP Cy 5.5, CD8 APC Cy7, CD27 FITC, CD45RA PE (eBioscience, CA, USA). The cells were also stained with monoclonal antibodies to MDSC phenotype CD3 APC, CD19 APC, CD56 APC, HLA-DR APC e-fluor 780, CD33 PerCP Cy5.5, CD11b PE, CD14 PE Cy7, CD15 FITC (eBioscience, CA, USA). After $30 \mathrm{~min}$ of incubation with monoclonal antibodies, in the dark and at $4^{\circ} \mathrm{C}$, the cells were washed with PBS and centrifuged. Living cells (based on forward and side scatter) were acquired in the FACS Canto II using the DIVA software (Becton Dickinson, USA). Further analyses of FACS data were performed using the 9.3 FLOWJO software (Tree Star, USA).

T lymphocytes were characterized as described previously (36).

Naïve: $\mathrm{CD}^{+} \mathrm{CD}^{+} \mathrm{CD} 45 \mathrm{RA}^{+} \mathrm{CD} 27^{+}$or $\mathrm{CD}^{+} \mathrm{CD}^{+} \mathrm{CD} 45 \mathrm{RA}^{+}$ $\mathrm{CD} 27^{+}$(Naïve).

Central memory: $\mathrm{CD}^{+} \mathrm{CD}^{+}{ }^{+} \mathrm{CD} 45 \mathrm{RA}^{-} \mathrm{CD} 27^{+}$or $\mathrm{CD} 3^{+} \mathrm{CD} 8^{+}$ $\mathrm{CD} 4 \mathrm{RA}^{-} \mathrm{CD}^{2} 7^{+}(\mathrm{CM})$.

Effector memory: $\mathrm{CD}^{+} \mathrm{CD}^{+} \mathrm{CD} 45 \mathrm{RA}^{-} \mathrm{CD} 27^{-}$or $\mathrm{CD}^{+} \mathrm{CD}^{+}$ $\mathrm{CD}^{2} \mathrm{RA}^{-} \mathrm{CD}^{-} 7^{-}(\mathrm{EM})$.
Effectormemoryre-expressingCD45RA:CD3 ${ }^{+} \mathrm{CD} 4{ }^{+} \mathrm{CD} 45 \mathrm{RA}^{+}$ $\mathrm{CD}_{27}{ }^{-}$or $\mathrm{CD}^{+} \mathrm{CD}^{+}{ }^{+} \mathrm{CD} 45 \mathrm{RA}^{+} \mathrm{CD} 27^{-}$(EMRA).

Myeloid-derived suppressor cells were characterized as:

$\mathrm{CD}^{-}{ }^{-\mathrm{CD}} 19^{-} \mathrm{CD}^{-} 6^{-} \mathrm{HLA}^{-} \mathrm{DR}^{-/ \text {low }} \mathrm{CD} 33^{+} \mathrm{CD} 11 \mathrm{~b}^{+} \mathrm{CD} 15^{+}$ granulocytic or

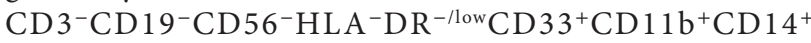
monocytic.

\section{ELISA}

The frozen culture supernatants were thawed and cytokines [IL-1, IL-2 $\alpha$, interleukin-6 (IL-6), IFN- $\gamma$, and TNF- $\alpha$ ] were evaluated by ELISA assay according to the manufacturer's instructions (DuoSet ELISA Development Systems R\&D). ELISA reading PerkinElmer-EnSpire, quantified the samples.

\section{Metabolic Data}

Obtained from the databank of SABE study.

\section{Cytomegalovirus IgM and IgG}

Serum was previously isolated by centrifugation and frozen stored $\left(-80^{\circ} \mathrm{C}\right)$. IgG and $\operatorname{IgM}$ levels were measured in serum by electrochemiluminescence immunoassay according to the manufacturer's instructions (cobas ${ }^{\circledR}$ http://e-labdoc.roche.com REF 04784618 190).

\section{Measurement of Vitamin D}

Serum of studied individuals was previously isolated by centrifugation and frozen stored $\left(-80^{\circ} \mathrm{C}\right)$ until the measurement of vitamin D. 25-Hydroxyvitamin D value was obtained in accordance with the manufacturer's instructions ( cobas $^{\circledR}$ http://e-labdoc. roche.com $05894913190 \mathrm{~V} 7)$.

\section{Statistics}

After testing the variables for normality (Shapiro-Wilk) it was used the unpaired Student's $t$-test (Vitamin D) or Mann-Whitney

TABLE 1 | Metabolic parameters in old individuals (80-100 years) and reference values of 80-year-old individuals (37).

\begin{tabular}{|c|c|c|c|c|c|c|c|c|}
\hline Age & Gender & Cholesterol total $\mathrm{mg} / \mathrm{dL}$ & HDL mg/dL & Triglycerides mg/dL & Glucose mg/dL & Urea mg/dL & Creatinine $\mathrm{mg} / \mathrm{dL}$ & Albumin $\mathrm{mg} / \mathrm{dL}$ \\
\hline 100 & $\mathrm{~F}$ & 179 & 38 & 183 & 162 & 35 & 0.91 & 3.1 \\
\hline 90 & $\mathrm{~F}$ & 224 & 53 & 178 & 80 & 33 & 1.09 & 3.4 \\
\hline 90 & $\mathrm{~F}$ & 188 & 73 & 125 & 86 & 42 & 0.67 & 3.9 \\
\hline 93 & $M$ & 181 & 43 & 47 & 80 & 57 & 0.98 & 3.9 \\
\hline 93 & $\mathrm{~F}$ & 186 & 51 & 121 & 93 & 28 & 0.93 & 3.6 \\
\hline 88 & $M$ & 275 & 68 & 114 & 104 & 36 & 1.01 & 4 \\
\hline 94 & $M$ & 177 & 39 & 86 & 71 & 47 & 1.26 & 3.4 \\
\hline 90 & $M$ & 163 & 43 & 72 & 82 & 30 & 1.1 & 3.7 \\
\hline 90 & $M$ & 181 & 38 & 135 & 95 & 43 & 1.22 & 3.9 \\
\hline 94 & $M$ & 132 & 33 & 80 & 90 & 61 & 1.97 & 3.9 \\
\hline 91 & $\mathrm{~F}$ & 207 & 63 & 106 & 81 & 41 & 0.73 & 4.3 \\
\hline 90 & $\mathrm{~F}$ & 236 & 58 & 109 & 90 & 29 & 0.94 & 4 \\
\hline \multicolumn{2}{|c|}{ Mean $\pm S D$} & $194.1 \pm 37.1$ & $50 \pm 13.1$ & $113 \pm 40.2$ & $92.8 \pm 2$ & $40.2 \pm 10.7$ & $1.1 \pm 0.3$ & $3.8 \pm 0.3$ \\
\hline \multicolumn{2}{|c|}{ Range } & 132-275 & $33-73$ & 47-183 & 71-162 & 28-61 & $0.67-1.97$ & $3.1-4.3$ \\
\hline \multicolumn{2}{|c|}{ Reference values } & 108.3-313.2 & $27.1-104.4$ & $43.8-287.8$ & 126 & $19.8-89.5$ & $0.52-1.94$ & $3.2-4.7$ \\
\hline
\end{tabular}

(37) 

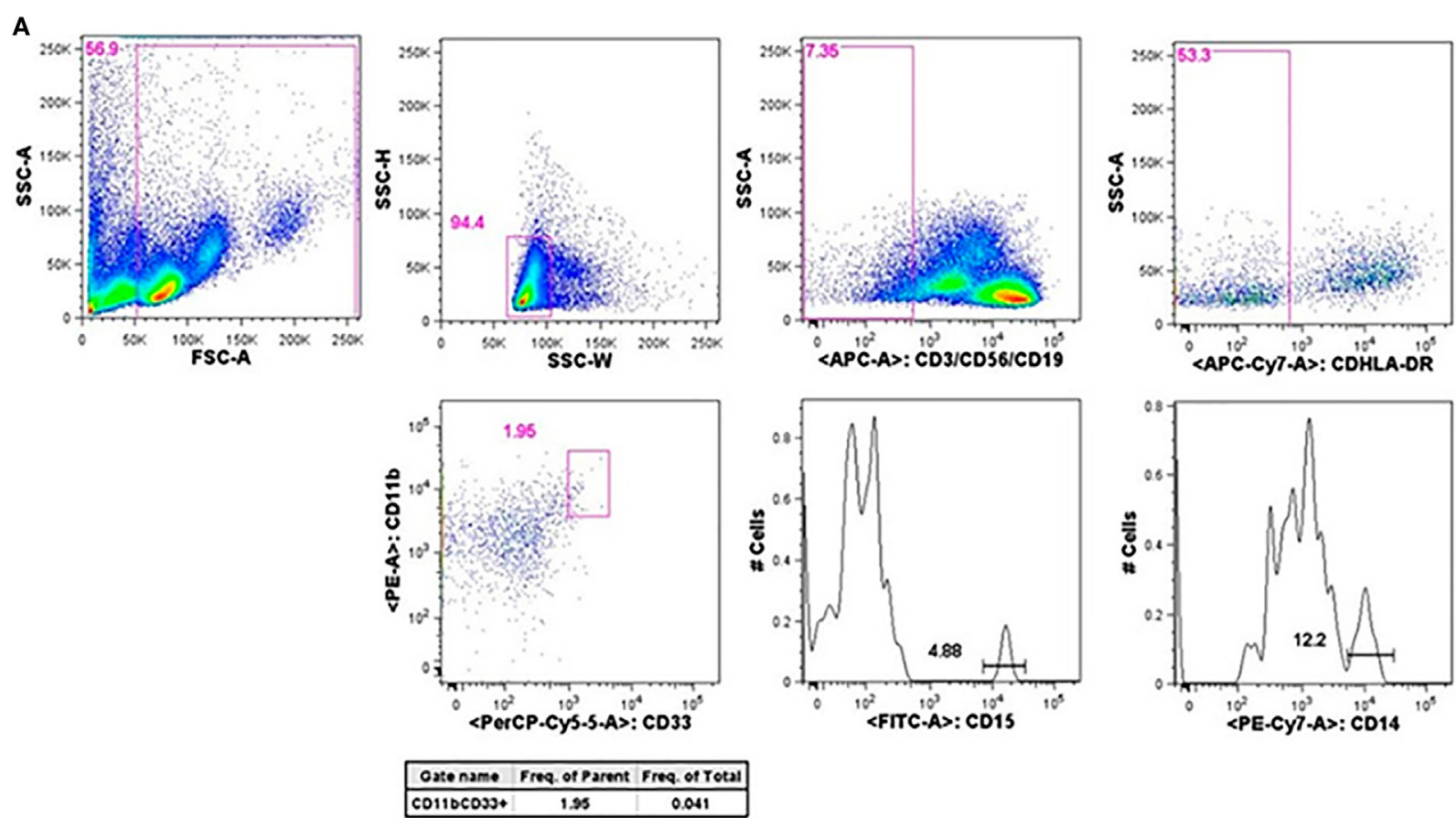

B
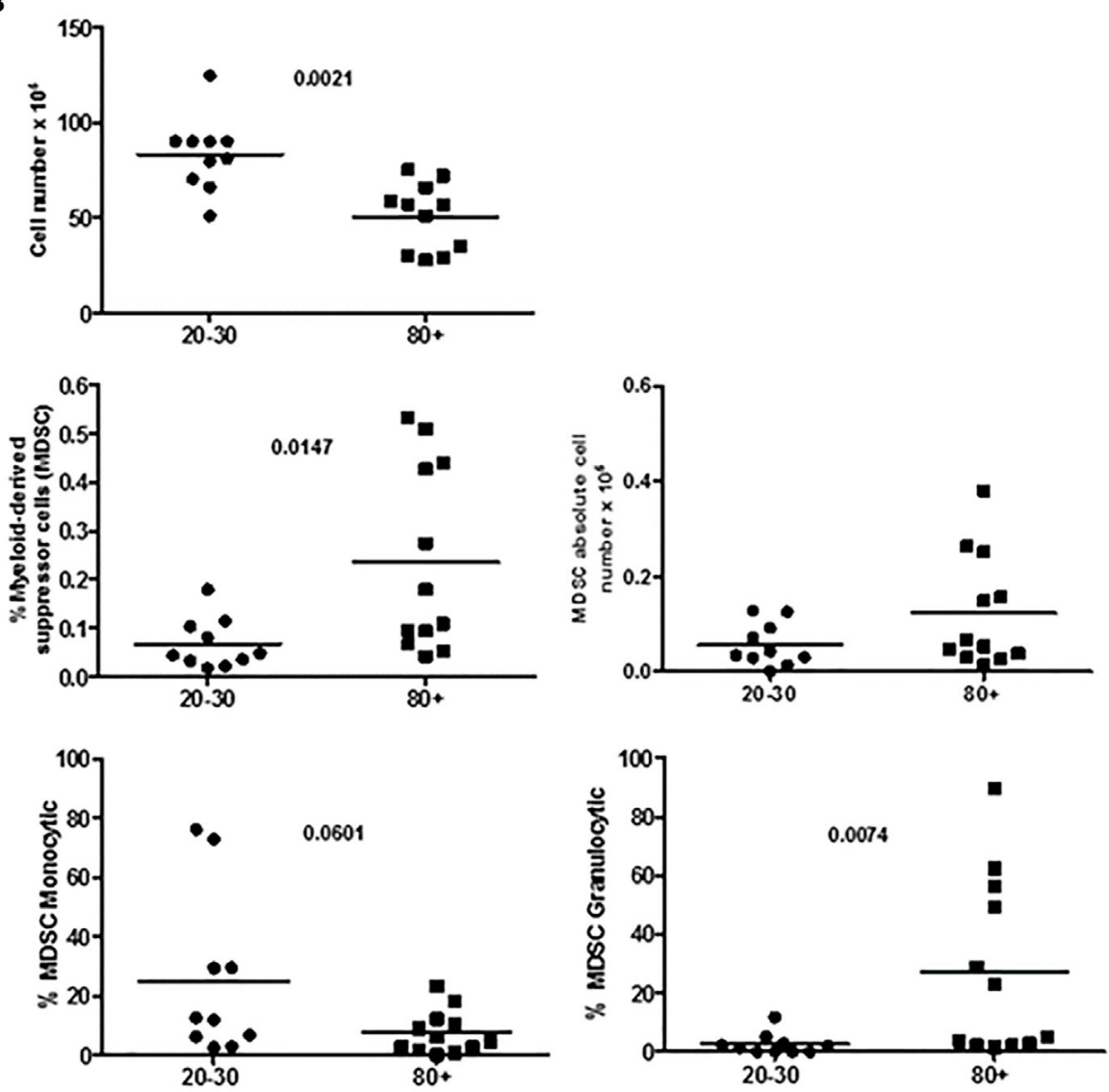

FIGURE 1 | Representative flow cytometry plots showing gate strategy for myeloid-derived suppressor cells (MDSC) frequency. Gate in live cells (FSC-A $\times$ SSC-A), doublets exclusion (SSC-H $\times$ SSC-W), gate in lineage negative cells (CD3-CD56-CD19-), gate in HLA-DR ${ }^{\text {low/neg }}$ cells, gate in CD33+CD11 b $^{+}$cells. Gate in granulocytic (CD15+) and monocytic (CD14+) cells (A). Number of circulating leukocytes, MDSC (\% MDSC) frequency, absolute number of MDSC, and frequency of monocytic and granulocytic MDSC in individuals of 20-30 years and 80+ years old individuals (B). 
(parameters of the immune system) for comparisons between young and old groups. The correlation between parameters of the immune system and serum levels of IgG (CMV) or vitamin D was performed by Spearman test. Values of $p<0.05$ were considered statistically significant. All statistical analyses were performed with the aid of the Graph Pad PRISM software (Graph pad, La Jolla, CA, USA).

\section{RESULTS}

Young ( $n=10,5$ male and 5 female, 20-30 years old) and old $(n=12,6$ male and 6 female, $80-100$ years old) individuals were evaluated. Table 1 shows some metabolic parameters that highlight the health status of the old population evaluated. In agreement with Helmersson-Karlqvist et al. (37), our old population may be considered healthy for most of the parameters evaluated in spite of great variability observed. Only one female (100 years) presented glucose $(162 \mathrm{mg} / \mathrm{dL})$ higher than the reference values established by Helmersson-Karlqvist et al. (37).
Figure 1 shows that old individuals (80-100 years) presented a significantly high percentage of MDSC (\%MDSC). However, as this group had a significantly lower number of leukocytes, the absolute cell number of MDSC (leukocytes cell number $\times$ percentage of MDSC) was not different compared to young individuals (20-30 years). There was significant predominance of granulocytic MDSC in individuals older than 80 years, while the subtype monocytic was statistically higher in young individuals. The percentage of $\mathrm{T} \mathrm{CD} 4^{+}$lymphocytes was similar in both groups while there was a trend toward lower percentage of $\mathrm{CD}^{+}$ $\mathrm{T}$ cells in old individuals $(p=0.0572)$. The CD4/CD8 ratio was significantly higher in old individuals except in a woman (96 years) with the CD4/CD8 ratio inverted (0.542) (Figure 2).

The evaluation of $\mathrm{T}$ cells phenotypes showed a significantly lower percentage of $\mathrm{CD}^{+}$central memory in elderly individuals (Figure 3). In the CD8 compartment, Naive cells were statistically less expressed in old individuals and CD8 ${ }^{+}$EMRA T cells presented significantly higher expression in old individuals
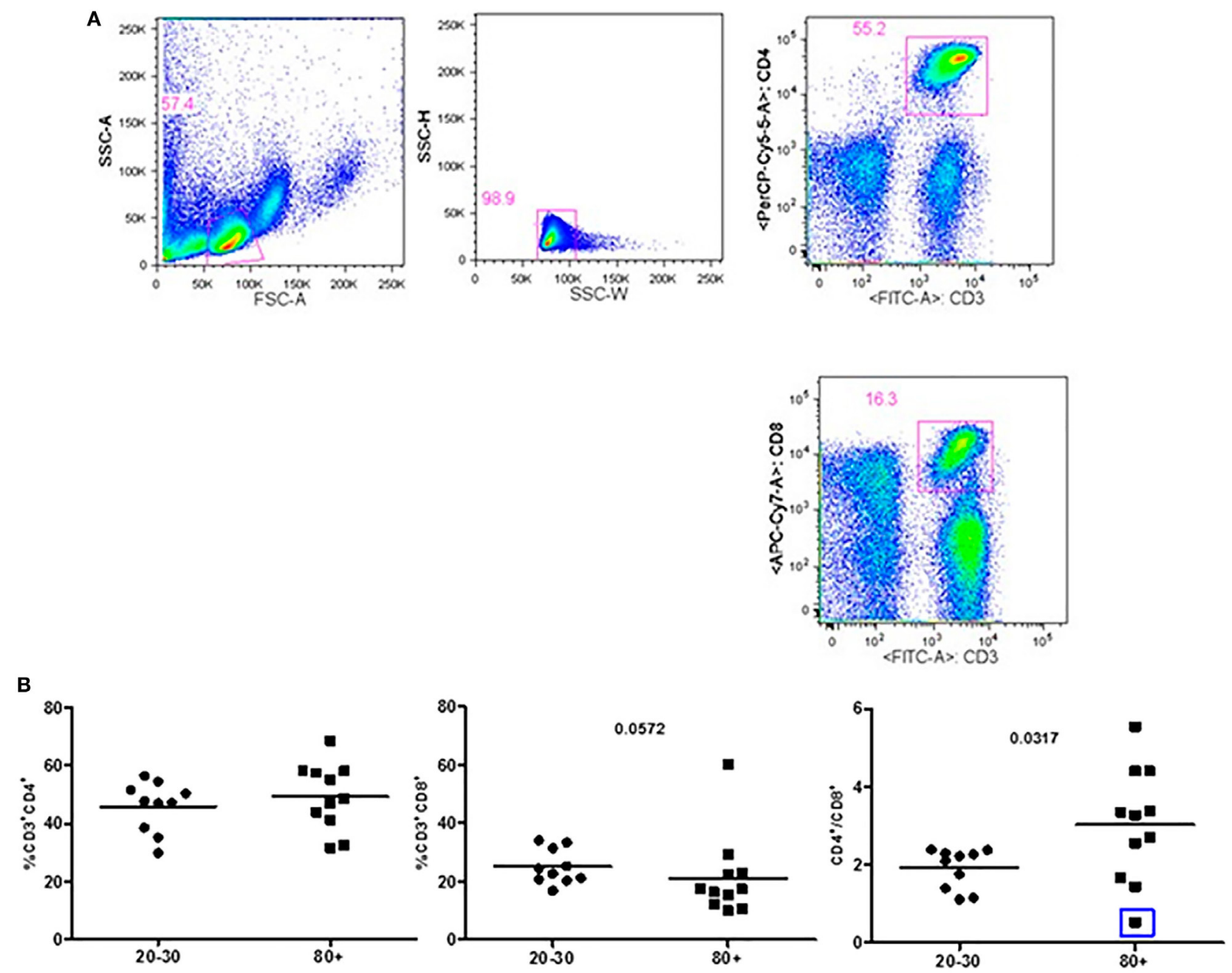

FIGURE 2 | Representative flow cytometry plots showing gate strategy for the frequency of CD4+ and CD8+ $\mathrm{T}$ cells. Gate in live lymphocytes (FSC-A $\times$ SSC-A), doublets exclusion (SSC-H $\times$ SSC-W), gate in $\mathrm{CD} 3^{+} \mathrm{CD} 4^{+} \mathrm{T}$ cells, gate in $\mathrm{CD} 3^{+} \mathrm{CD} 8^{+} \mathrm{T}$ cells $(\mathbf{A})$. Frequency of $\mathrm{T}$ lymphocytes $\mathrm{CD} 3^{+} \mathrm{CD} 4^{+}, \mathrm{CD} 3^{+} \mathrm{CD} 8^{+}$, and $\mathrm{CD} 4 / \mathrm{CD} 8$ ratio in 20-30 and $80^{+}$years old individuals. The CD4/CD8 ratio lower than 1 (0.542; blue square) (B). 


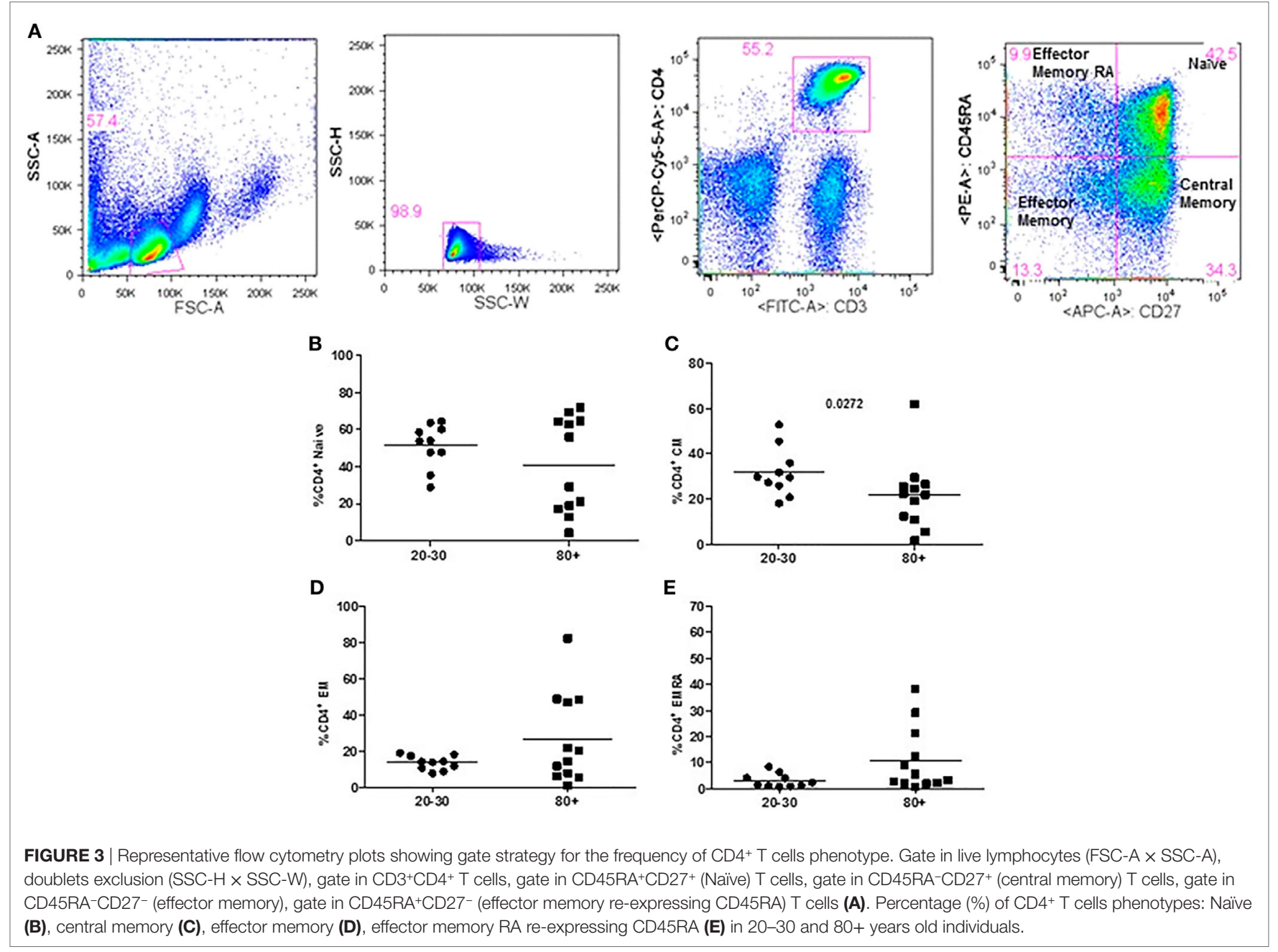

(Figure 4). Considering the functions of T cells after stimulation in culture with PHA, the percentage of proliferation was lower in old individuals both in the compartment $\mathrm{CD}^{+}$and $\mathrm{CD}^{+}$(Figure 5). The production of cytokines was reduced in old individuals with statistical difference for IL-6 and TNF- $\alpha$ (Figure 6). As cytomegalovirus infection/latency has been related to immunosenescence, we evaluated IgM and IgG against CMV in serum of old (80-100 years) individuals (Table 2) and the possible correlation with immune parameters (Table 3 ).

Table 2 shows that in 12-old individuals evaluated, only one male ( 88 years old) can be considered negative for cytomegalovirus as the IgM level was $<0.7(0.158)$ and IgG level was $<0.5(<0.25)$. In addition, only one male ( 90 years old) could be considered as recently infected by CMV as the IgM level was $>1.0$ (1.240) and the IgG level was relatively low (55.85) in comparison to other old individuals studied. Levels of $\operatorname{IgG}>500 \mathrm{U} / \mathrm{mL}$ were observed in four individuals ( 3 females and 1 male).

The levels of IgG against CMV were negatively correlated $(p=0.027)$ with the percentage of Naïve $\mathrm{CD}^{+} \mathrm{T}$ cells. There was a trend of negative correlation $(p=0.06)$ between the percentage of $\mathrm{CD}^{+}$central memory T cells and IgG levels (CMV). A trend of positive correlation $(p=0.055)$ between the percentage of $\mathrm{CD}^{+}$ EMRA T cells and IgG levels (CMV) was observed (Table 3).

The next question was whether total vitamin $\mathrm{D}$ levels were different in the studied groups (Figure 7). Vitamin D levels were lower in old individuals $(p=0.050)$. In $50 \%(n=6)$ of aged individuals vitamin D levels were $<20 \mathrm{ng} / \mathrm{mL}$ (deficiency) and in $90 \%(n=9)$ of young individuals vitamin $\mathrm{D}$ levels were greater than $20 \mathrm{ng} / \mathrm{mL}$. Insufficiency $(21-29 \mathrm{ng} / \mathrm{mL})$ was present in $25 \%$ $(n=3)$ of old individuals and $50 \%(n=5)$ of young individuals. Sufficient levels (30 ng/mL or more) were observed in $25 \%$ $(n=3)$ of aged and $40 \%(n=4)$ of young individuals.

It was analyzed whether total vitamin $\mathrm{D}$ was correlated with the immunological parameters evaluated previously. We observed correlation of vitamin D levels only for the CD8 compartment (Table 4). The percentage of total CD8 T cells was positively correlated $(p=0.006)$ with vitamin D levels in old individuals, whereas there was a trend toward positive correlation $(p=0.074)$ in young individuals. $\mathrm{CD}^{+}$effector memory $\mathrm{T}$ cells were positively correlated with vitamin D levels in young individuals and CD8 ${ }^{+}$EMRA T cells were negatively correlated $(p=0.05)$ with vitamin $\mathrm{D}$ levels in old individuals. 


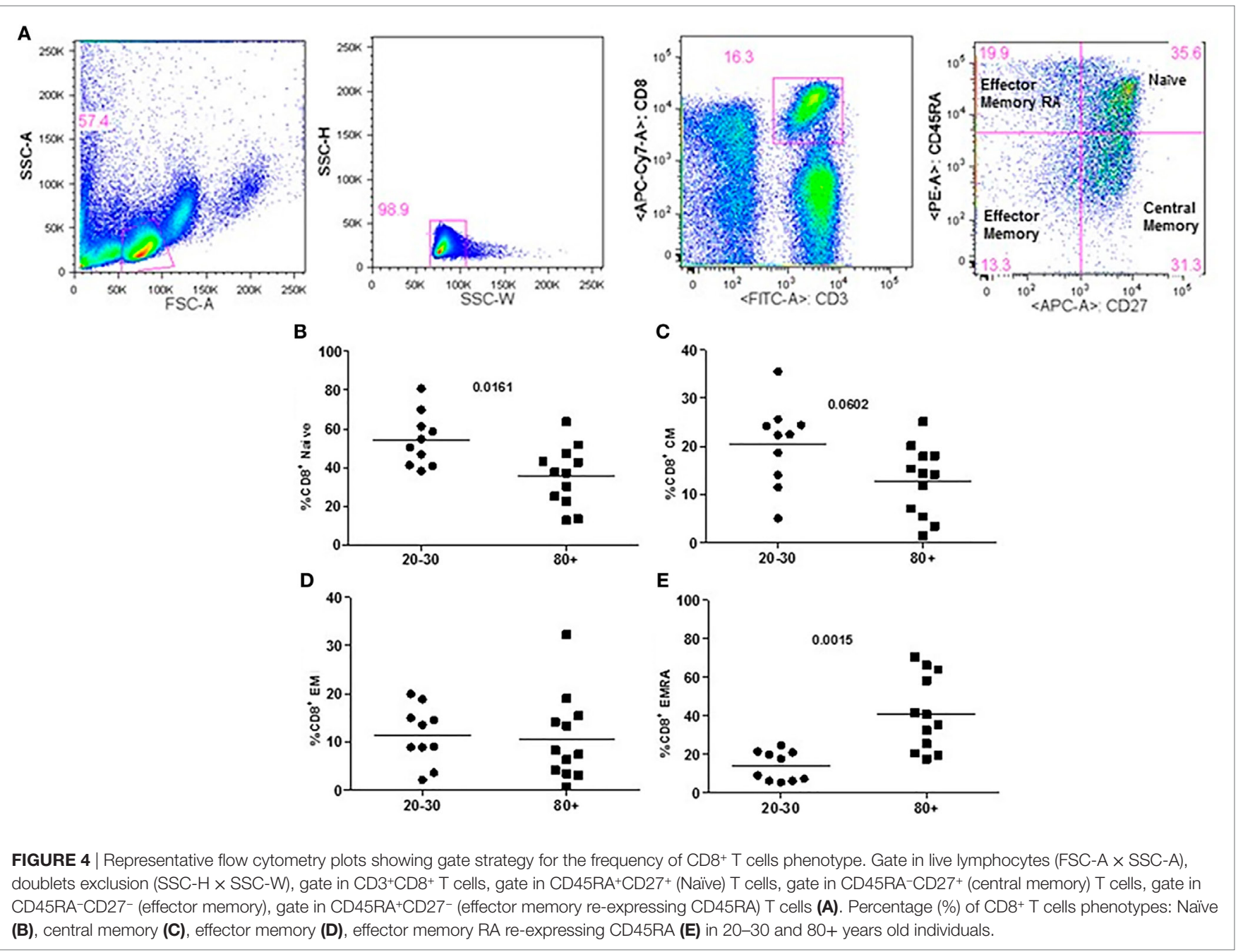

\section{DISCUSSION}

Morbidities associated with aging contribute to organ failure that leads to a pathway of poor quality of life and/or death. In addition, the impairment in the protective functions of the immune system promoting infections and tumors, and the increase of inflammatory factors causing tissue damage and contributing for age-related diseases have also been reported in old individuals.

In our study, it was observed that old individuals presented metabolic parameters consistent with healthy aging except for a female (100 years) with blood glucose higher than $126 \mathrm{mg} / \mathrm{dL}$. Our data are in agreement with the report of HelmerssonKarlqvist et al. (37) who have developed reference intervals of metabolic parameters adjusted for very old (80 years) individuals.

Despite our studied population could be considered healthy, we observed characteristics reported as immune senescence.

Myeloid-derived suppressor cells were only recently described as potential markers of the aging process, since these cells were initially associated with tumor development (12). We observed in old individuals that MDSC were present in high percentage with predominance of the granulocytic subtype. It has been reported that the accumulation of MDSC with aging may contribute to some of the immune disorders and pathologies observed in older adults (12). In aging individuals, Verschoor et al. observed a significant increase in the frequency of MDSC compared to young adults in addition to the higher number of MDSC in older individuals with frailty and previous history of cancer (11). In addition to the increased percentage of MDSC, our old population presented decreased number of circulating leukocytes, reduced percentage of total $\mathrm{CD}^{+}$and $\mathrm{CD}^{+}$Naïve $\mathrm{T}$ cells, and increase in the percentage of terminally differentiated CD8 ${ }^{+}$EMRA T cells. Significant changes in the phenotype and function occurred mainly in $\mathrm{CD}^{+} \mathrm{T}$ cells in these individuals and are in agreement with the literature (38-43). In addition, it has been shown that the homeostatic proliferation is less effective for CD8 than for CD4 Naïve T cells (44).

In old individuals, it has been shown that many aspects of immunosenescence are related to the seropositivity for cytomegalovirus (CMV). However, it seems that the effects of CMV in the immune system of healthy old individuals are dependent on the increased latency of the virus $(45,46)$. In our study, 11 out of 12 old individuals were seropositive for CMV and four individuals presented 

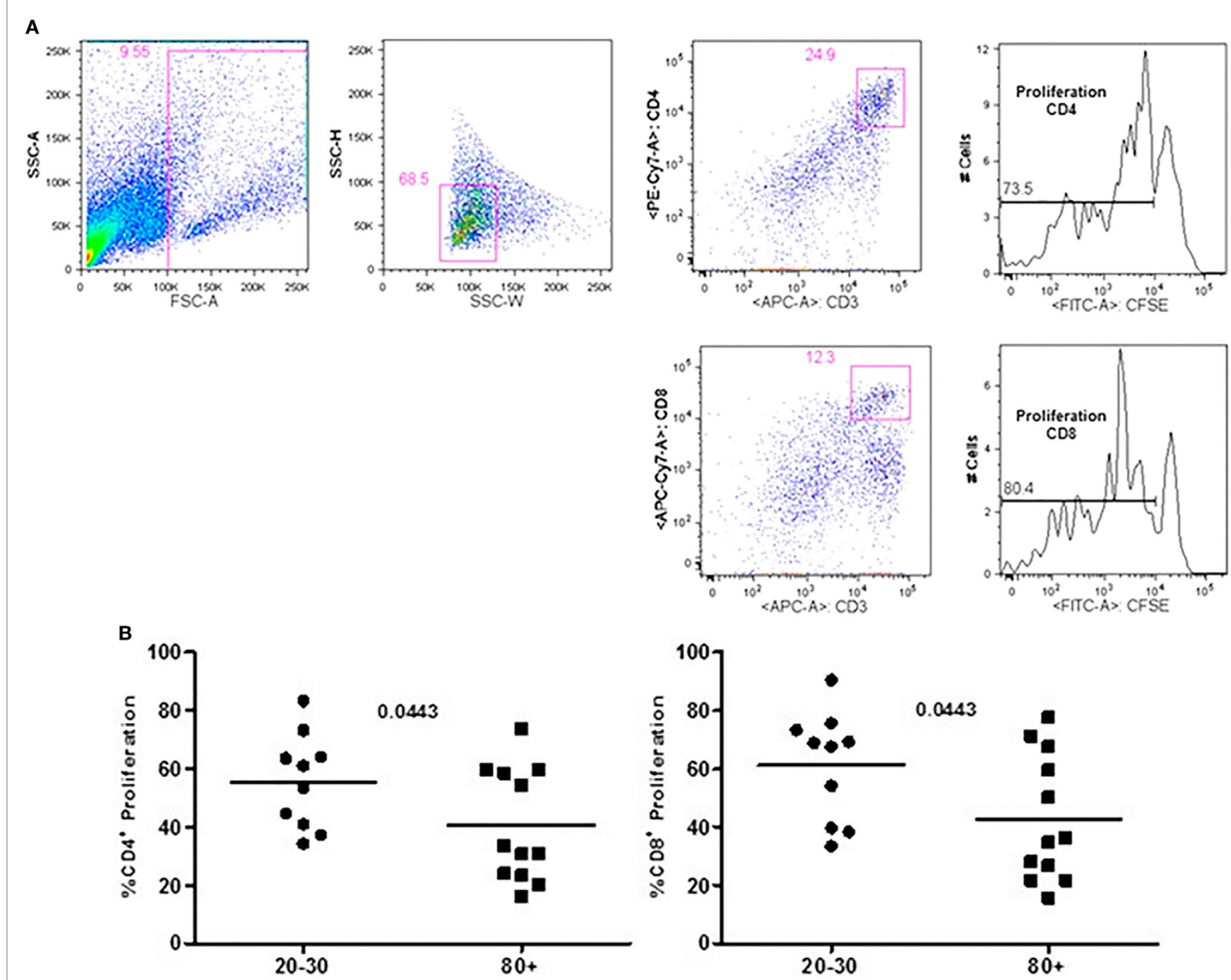

FIGURE 5 | Representative flow cytometry plots showing gate strategy for the frequency of proliferation in $\mathrm{CD} 4^{+}$and $\mathrm{CD} 8^{+} \mathrm{T}$ cells after stimulus with phytohemagglutinin (PHA) in culture. Gate in live cells (FSC-A $\times$ SSC-A), doublets exclusion (SSC-H $\times$ SSC-W), gate in $\mathrm{CD}^{+} \mathrm{CD} 4^{+} \mathrm{T}$ cells, gate in the decrease of CFSE, gate in $\mathrm{CD}^{+} \mathrm{CD} 8^{+} \mathrm{T}$ cells, gate in the decrease of CFSE (A). Percentage of $\mathrm{CD} 3^{+} \mathrm{CD} 4^{+}$and $\mathrm{CD} 3^{+} \mathrm{CD} 8^{+} \mathrm{T}$ cells proliferation after stimulus with $\mathrm{PHA}$ according to age: $20-30$ and $80+$ years old (B).

IgG levels $>500 \mathrm{U} / \mathrm{mL}$. The seropositivity to CMV was correlated with the decrease of Naive $\mathrm{CD} 8^{+} \mathrm{T}$ cells and with a trend toward decrease in $\mathrm{CD}^{+}$central memory $\mathrm{T}$ cells and increase in $\mathrm{CD}^{+}$ EMRA T cells. The impact of CMV infection/latency in immunity can exacerbate the features of immunosenescence. However, some of the features reported in literature were not in agreement with our studied old individuals such as the decrease in Naïve $\mathrm{CD} 4^{+}$ $\mathrm{T}$ cells and CD4/CD8 ratio in addition to the increase in $\mathrm{CD}^{+}$and $\mathrm{CD}^{+}$central memory, $\mathrm{CD}^{+}$effector memory $\mathrm{T}$ cells, and proinflammatory cytokines $(39,47,48)$. These differences may be due to the small number of individuals and great variability observed in the frequency of cell subtypes and cytokine production in our study population. Nonetheless, it cannot be ruled out by the possibility that the features preserved in immune system and observed in the old individuals studied are the key to achieve the longevity $(13,49,50)$. Arai et al. (49) found in two different Japanese cohorts ( $n=1,554)$ evaluating very old individuals (85-99 years), centenarians, and individuals $\geq 105$ years that the lowest levels of inflammation correlated with the main indicators markers of successful aging, such as survival, capability, and cognition.

In old individuals, we observed lower rates of proliferation in CD4 and CD8 compartments in addition to the reduced levels of cytokines after stimulation with PHA. In association, we found lower percentage of $\mathrm{CD}^{+}$central memory $\mathrm{T}$ cells, which have been described as highly proliferative, and producers of IL-2 (13, 49-53). Corroborating with our data, Whisler et al. (51) showed that in in vitro there were diminished proliferative capacity and decreased production of IL-2 after stimulation with 

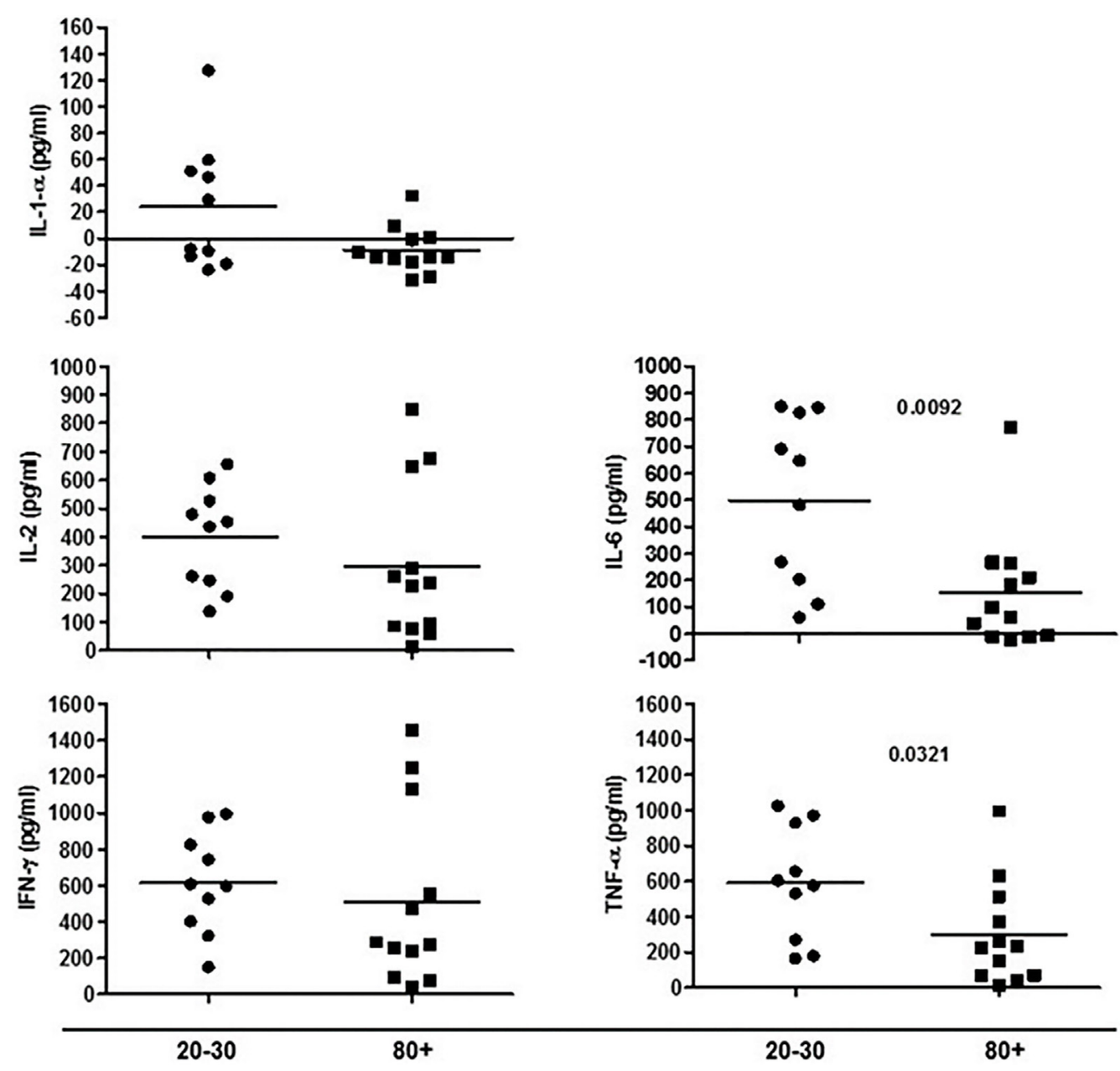

FIGURE 6 | Cytokines produced by cells in culture under phytohemagglutinin stimulus according to age: 20-30 and 80+ years old.

TABLE 2 | Serum levels of IgM and lgG to cytomegalovirus in old (80-100 years) individuals.

\begin{tabular}{lccc}
\hline Age & Gender & IgM & IgG \\
\hline 100 & F & 0.159 & $>500$ \\
90 & F & 0.296 & 240.60 \\
90 & F & 0.164 & $>500$ \\
93 & M & 0.237 & 316.30 \\
93 & F & 0.160 & 31.36 \\
88 & M & 0.158 & $<0.25$ \\
94 & M & 0.436 & 153.90 \\
90 & M & 1.240 & 55.85 \\
90 & M & 0.189 & $>500$ \\
94 & M & 0.157 & 180.60 \\
91 & F & 0.488 & $>500$ \\
90 & F & 0.428 & 87.39 \\
\hline
\end{tabular}

IgM cutoff index negative: $<0.7$; indeterminate: 0.7-0.99; positive: $\geq 1.0$.

IgG negative $<0.5 \mathrm{U} / \mathrm{mL}$; indeterminate: $0.5-0.99 \mathrm{U} / \mathrm{mL}$; positive: $\geq 1.0 \mathrm{U} / \mathrm{mL}$.

PHA in 7 out of 12 old individuals evaluated (mean age 78 years) in association with deficient activation of transcriptional factor AP-1 and nuclear factor of activated T cells.
Others have reported that age interferes negatively with the expansion of $\mathrm{T}$ cells due to telomere erosion $(52,53)$. On the other hand, after vaccination with live attenuated virus varicella zoster Qi et al. (54) observed that the majority of activated T cells were $\mathrm{CD}^{+}$and age (50-70 years) did not interfere with the expansion of antigen-specific T cells. However, the long-lived memory $\mathrm{T}$ cells (production of IFN- $\gamma$ in vitro) decreased from day 14 to 28 post-vaccination.

The study of Shahid et al. (55) showed reduced expression of IFN- $\gamma$ and granzyme B in CD8 ${ }^{+} \mathrm{T}$ cells of older adults vaccinated against influenza.

Our findings show that despite the common features of immune senescence presented by old individuals, they managed to achieve longevity.

Health professionals have proposed alternatives to circumvent age-associated diseases, such as physical activity, diet control, supplements, and probiotics (22-24). Vitamin D has been recommended due to its action on the immunity, but data from literature are inconclusive regarding the benefits of supplementation with vitamin D. 
TABLE 3 | IgG levels against cytomegalovirus and correlation with parameters of the immune system in old (80-100 years) individuals.

\begin{tabular}{|c|c|c|}
\hline Parameters & $r$ Spearman & $p$ \\
\hline Cell number $\times 10^{5}$ & -0.164 & 0.6054 \\
\hline $\begin{array}{l}\text { \% Myeloid-derived suppressor cells (MDSC) } \\
\left(\mathrm{CD} 33^{+} \mathrm{CD} 11 \mathrm{~b}^{+}\right)\end{array}$ & 0.071 & 0.8267 \\
\hline MDSC absolute cell number $\times 10^{5}$ & 0.046 & 0.883 \\
\hline \% CD15 MDSC & -0.267 & 0.397 \\
\hline$\%$ CD14 MDSC & -0.377 & 0.225 \\
\hline$\% \mathrm{CD}^{+} \mathrm{CD}^{+}{ }^{+}$ & -0.209 & 0.532 \\
\hline$\% \mathrm{CD}^{+} \mathrm{CD}^{+}$ & 0.107 & 0.753 \\
\hline CD4/CD8 & -0.191 & 0.566 \\
\hline \% Proliferation CD4+ & 0.259 & 0.410 \\
\hline \% Proliferation CD8+ & 0.085 & 0.792 \\
\hline$\%$ CD4+ Naïve & -0.135 & 0.673 \\
\hline$\% \mathrm{CD}^{+}{ }^{+}$central memory & -0.559 & 0.06 \\
\hline$\%$ CD4+ effector memory & 0.295 & 0.347 \\
\hline$\% \mathrm{CD}^{+}{ }^{+}$effector memory RA & 0.499 & 0.100 \\
\hline \% CD8+ Naïve & -0.648 & 0.027 \\
\hline$\%$ CD8+ central memory & -0.420 & 0.174 \\
\hline$\%$ CD4+ effector memory & 0.085 & 0.792 \\
\hline$\%$ CD8+ effector memory RA & 0.573 & 0.055 \\
\hline$\| L-1 \alpha$ & -0.346 & 0.276 \\
\hline $\mathrm{IL}-2$ & 0.025 & 0.941 \\
\hline Interleukin-6 & 0.143 & 0.652 \\
\hline $\mathrm{IFN}-\gamma$ & 0.110 & 0.731 \\
\hline Tumor necrosis factor-alpha & 0.075 & 0.818 \\
\hline Vitamin D & 0.302 & 0.336 \\
\hline
\end{tabular}

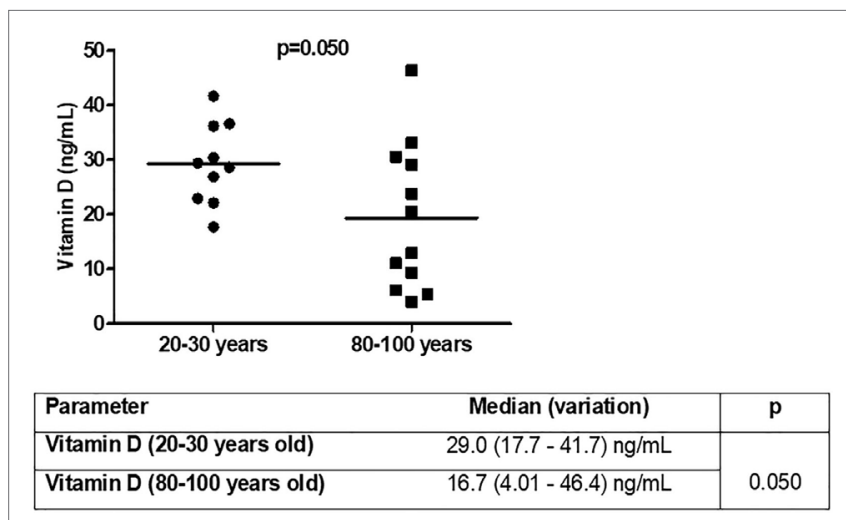

FIGURE 7 | Vitamin D [25(OH)D3] levels in young ( $n=10 ; 20-30$ years) and old ( $n=12 ; 80-100$ years) individuals.

The US Endocrine Society defined vitamin D levels of $20 \mathrm{ng} / \mathrm{mL}$ or less as deficiency, 21-29 ng/mL as insufficiency, and $30 \mathrm{ng} / \mathrm{mL}$ or more as sufficiency (56). However, suboptimal levels of vitamin $\mathrm{D}$ have been reported worldwide and depending on the lifestyle and environmental conditions, hypovitaminosis D could be observed in all age groups (57). In old adults, the diminished sun exposure, skin atrophy with decreased amounts of the precursor 7-dehydrocholesterol, and the reduced content of vitamin $\mathrm{D}$ in the diet leads to lower serum levels of vitamin D $(58,59)$. In accordance, blood samples were collected in summer and yet we observed that $50 \%$ of individuals older than 80 years showed vitamin D deficiency, while the insufficiency was observed in 50\% of young individuals.

In innate immunity, macrophages and dendritic cells can convert vitamin D3 on biological active $1,25 \mathrm{OH}$ (60). In addition, immune cells also express the vitamin D receptor (VDR) and thus $1,25 \mathrm{OH}$ can act on immune microenvironment in paracrine and autocrine pathways (61).

Human monocytes activated through TLR upregulate the expression of genes associated with the conversion of $25 \mathrm{OH}$ to $1,25 \mathrm{OH}$ (Cyp27B1) and VDR. The addition of vitamin D to monocytes in culture leads to upregulation of VDR downstream genes, such as the antimicrobial cathelicidin (62-64). In opposition, it was observed that in adaptive immunity, vitamin D added in culture abolished the production of IFN- $\gamma$ and IL-17 by $\mathrm{CD}^{+}$memory $\mathrm{T}$ cells co-cultured with activated dendritic cells (pneumococci products) (65). Accordingly, Rode et al. (66) found that human $\mathrm{CD}^{+} \mathrm{T}$ cells stimulated with $\mathrm{CD} 3 / \mathrm{CD} 28$ beads in the presence of $25 \mathrm{OH}$ or $1,25 \mathrm{OH}$ present reduced production of IFN- $\gamma$.

In this study, there was a trend toward negative correlation between the absolute number of MDSC and vitamin D levels ( $r=-0563 p=0.089)$ in young individuals. This is an important finding, since there was a higher percentage of MDSC in old individuals with predominance of the granulocytic phenotype $\left(\mathrm{CD} 33^{+} \mathrm{CD} 11 \mathrm{~b}^{+} \mathrm{CD} 15^{+}\right)$that has been associated with some types of cancer in humans. In addition, these cells have recently been associated with frailty and Alzheimer's disease $(11,67)$.

Interventions to circumvent the MDSC increase have been proposed such as the use of vitamin D to induce the differentiation of non-mature suppressive myeloid cells into mature effector non-suppressive cells (68). In patients (49-71 years old) with head and neck cancer, vitamin D3 (20, 40, $60 \mu \mathrm{g} /$ day) decreased the number of progenitor cells with suppressive phenotype, promoted the proliferation of $\mathrm{T}$ cells after in vitro stimulation, and increased the levels of effector cytokines (IL12 and IFN- $\gamma$ ) (69).

Regarding to the $\mathrm{CD}^{+}{ }^{+} \mathrm{T}$ cell compartment there was no correlation with the levels of vitamin $\mathrm{D}$ which is in agreement with literature data showing that for young adults, vitamin D levels (70), or supplement $(71,72)$ previously to vaccination did not cause enhanced humoral immunity that is dependent of $\mathrm{CD} 4^{+} \mathrm{T}$ cells help. However, Khoo et al. (73) showed that during winter the level of vitamin D decreases and is associated with lower percentage of Naive $\mathrm{CD}^{+} \mathrm{T}$ cells suggesting a role played by vitamin $\mathrm{D}$ in this cell compartment.

Our data points for correlation of vitamin D levels with some parameters of $\mathrm{CD}^{+} \mathrm{T}$ cells. In old individuals, vitamin $\mathrm{D}$ had a positive correlation with total $\mathrm{CD}^{+} \mathrm{T}$ cells. Considering that we observed a trend toward lower percentage of $\mathrm{CD}^{+} \mathrm{T}$ cells in old individuals (Figure 2), vitamin D could be beneficial in preventing the decrease of this cell subtype. In young individuals, vitamin D levels correlated positively with the frequency of $\mathrm{CD}^{+}$ effector memory T cells.

Another important result was the negative correlation between vitamin D and CD8 EMRA T cells in old individuals suggesting that higher levels of vitamin $\mathrm{D}$ would be linked to less 
TABLE 4 | Vitamin D [25(OH)D3] levels and correlation with parameters of the immune system in young (20-30 years) and old (80-100 years) individuals.

\begin{tabular}{|c|c|c|c|c|}
\hline Parameters & $r$ Spearman $20-30$ years & $p$ & $r$ Spearman $80-100$ years & $p$ \\
\hline Cell number $\times 10^{5}$ & 0.012 & 0.973 & -0.182 & 0.571 \\
\hline \% Myeloid-derived suppressor cells (MDSC) (CD33+CD11b+) & -0.527 & 0.117 & 0.370 & 0.235 \\
\hline MDSC absolute cell number $\times 10^{5}$ & -0.563 & 0.089 & 0.181 & 0.571 \\
\hline$\%$ CD15 MDSC & 0.281 & 0.431 & 0.167 & 0.602 \\
\hline$\%$ CD14 MDSC & -0.176 & 0.626 & 0.168 & 0.602 \\
\hline$\% \mathrm{CD}^{+} \mathrm{CD}^{+}+$ & 0.442 & 0.200 & 0.190 & 0.574 \\
\hline$\% \mathrm{CD}^{+} \mathrm{CD}^{+}$ & 0.588 & 0.074 & 0.764 & 0.006 \\
\hline CD4/CD8 & -0.090 & 0.803 & -0.547 & 0.082 \\
\hline$\%$ Proliferation CD4+ & 0.345 & 0.328 & -0.238 & 0.457 \\
\hline$\%$ Proliferation CD8+ & 0.236 & 0.511 & -0.126 & 0.697 \\
\hline$\% \mathrm{CD}^{+}{ }^{+}$Naïve $\mathrm{CD}^{+}{ }^{+} \mathrm{CD} 4+{ }^{+} \mathrm{CD} 45 \mathrm{RA}^{+} \mathrm{CD} 27^{+}$ & -0.109 & 0.764 & -0.027 & 0.931 \\
\hline$\% \mathrm{CD}^{+}{ }^{+}$central memory $\mathrm{CD}^{+}{ }^{+} \mathrm{CD} 4{ }^{+} \mathrm{CD} 45 \mathrm{RA}^{-} \mathrm{CD} 27^{+}$ & -0.079 & 0.829 & 0.287 & 0.366 \\
\hline$\% \mathrm{CD}^{+}{ }^{+}$effector memory $\mathrm{CD}^{+}{ }^{+} \mathrm{CD} 4{ }^{+} \mathrm{CD} 45 \mathrm{RA}^{-} \mathrm{CD} 27^{-}$ & -0.042 & 0.907 & 0.028 & 0.931 \\
\hline$\% \mathrm{CD}^{+}{ }^{+}$effector memory RA CD3+CD4+CD45RA+CD27- & 0.150 & 0.701 & -0.192 & 0.548 \\
\hline$\% \mathrm{CD}^{+}{ }^{+}$Naïve $\mathrm{CD}^{+}{ }^{+} \mathrm{CD} 8+\mathrm{CD} 45 \mathrm{RA}^{+} \mathrm{CD} 27^{+}$ & -0.297 & 0.405 & 0.378 & 0.269 \\
\hline$\% \mathrm{CD}^{+}$central memory $\mathrm{CD}^{+}{ }^{+} \mathrm{CD} 8{ }^{+} \mathrm{CD} 45 \mathrm{RA}^{-} \mathrm{CD} 27^{+}$ & 0.236 & 0.511 & 0.462 & 0.131 \\
\hline$\% \mathrm{CD}^{+}$effector memory $\mathrm{CD} 3^{+} \mathrm{CD} 8^{+} \mathrm{CD} 45 \mathrm{RA}-\mathrm{CD} 27^{-}$ & 0.697 & 0.025 & 0.260 & 0.467 \\
\hline$\% \mathrm{CD}^{+}$effector memory RA CD3+CD8+CD45RA+CD27- & 0.188 & 0.603 & -0.552 & 0.050 \\
\hline $\mathrm{IL}-1 \alpha(\mathrm{pg} / \mathrm{mL})$ & -0.472 & 0.169 & 0.505 & 0.094 \\
\hline $\mathrm{IL}-2$ (pg/mL) & 0.030 & 0.934 & -0.266 & 0.404 \\
\hline Interleukin-6 (pg/mL) & -0.151 & 0.676 & -0.246 & 0.442 \\
\hline $\mathrm{IFN}-\gamma(\mathrm{pg} / \mathrm{mL})$ & -0.491 & 0.150 & -0.014 & 0.966 \\
\hline Tumor necrosis factor-alpha $(\mathrm{pg} / \mathrm{mL})$ & 0.212 & 0.556 & -0.133 & 0.681 \\
\hline
\end{tabular}

accumulation of cells that have been described as a marker of senescence $(74,75)$.

There was no correlation of vitamin $\mathrm{D}$ levels and proliferation of $\mathrm{T}$ cells $\left(\mathrm{CD}^{+}\right.$and $\left.\mathrm{CD}^{+}\right)$or production of cytokines after stimulation with PHA. In agreement, the addition of vitamin D to culture of T cells stimulated with $\mathrm{CD} 3$ and $\mathrm{CHO}-\mathrm{CD} 80$ cell line did not increase the proliferative capacity (individuals from 32 to 57 years old) (76). In addition, PBMCs stimulated in vitro in the presence of vitamin D showed diminished IFN- $\gamma$ and increased IL-4 production in culture supernatant (77).

Aging has been related to chronic low-grade inflammation (inflammaging) with increased levels of circulating C-reactive protein (CPR), IL- 6 , and TNF- $\alpha$. The InCHIANTI study found that individuals ( $n=867$, mean age 75.1 years) with vitamin $\mathrm{D}$ levels lower than $31.4 \mathrm{nmol} / \mathrm{L}$ presented high circulating IL-6, but not TNF- $\alpha$, IL- $1 \alpha$, and IL-18 (78).

The English Longitudinal Study of Aging assessed communitydwelling individuals ( $n=5,870,50-80$ years) and reported that low levels of $25 \mathrm{OH}(\leq 30 \mathrm{nmol} / \mathrm{L})$ were negatively associated with CPR (79). A follow-up of old individuals ( $n=23,55-86$ years) for 12 months showed that vitamin D levels were significantly lower in the winter with an increase in the number of individuals presenting deficiency. In the same season, there was a significant increase of circulating IL-6, IL- 8 , IL- $\beta-1$, MCP- 1 , and TNF- $\alpha$ (80). The low-grade chronic inflammation has been associated with aging-related diseases, and suboptimal levels of vitamin D have been related to chronic diseases/overall mortality (81-84), suggesting that adequate levels of vitamin $\mathrm{D}$ could benefit the aging population.

Despite the size of the sample be a limitation of the study and not allow more detailed statistical analyses, after testing the variables for normality and applying the adequate statistics, we obtained some important results. We found that the old population evaluated could be considered healthy based on the metabolic parameters. In this sample, 11 out of 12 were $\mathrm{CMV}^{+}$ and still maintained preserved some features of immunity such as CD4/CD8 ratio, and low production of inflammatory cytokines after stimulus. On the other hand, we observed increased frequency of MDSC, reduced number of circulating leukocytes, reduced percentage of total $\mathrm{CD}^{+}$and Naïve $\mathrm{CD}^{+} \mathrm{T}$ cells, and increased percentage of terminally differentiated $\mathrm{CD} 8^{+} \mathrm{EMRA}$ $\mathrm{T}$ cells. $\mathrm{CMV}^{+}$was correlated with the decrease of $\mathrm{CD}^{+}$Naïve $\mathrm{T}$ cells and increase in $\mathrm{CD} 8^{+}$EMRA T cells. Vitamin D levels were insufficient in $50 \%$ of old individuals and correlated positively with total $\mathrm{CD} 8^{+} \mathrm{T}$ cells and negatively with CD8 EMRA T cells. Our next step is to develop an ex vivo model to study the action of vitamin $\mathrm{D}$ in $\mathrm{CD}^{+}$and $\mathrm{CD}^{+} \mathrm{T}$ cells, associated phenotypes, proliferation, and cytokines production.

\section{CONCLUSION}

In the studied population, longevity was correlated to maintenance of some immune parameters. Considering the limitations of the study as size of the sample and lack of functional assays showing the direct effect of vitamin D in immunity, it was found that vitamin $\mathrm{D}$ in old individuals was correlated to some features of the immune system, mainly in the CD8 compartment.

\section{ETHICS STATEMENT}

This study was carried out in accordance with the recommendations of "UNIFESP CEP Committee of Ethics in Research" with written informed consent from all subjects. All subjects gave written informed consent in accordance with the Declaration of 
Helsinki. The protocol was approved by the "CEP Committee of Ethics in Research.”

\section{AUTHOR CONTRIBUTIONS}

All authors contributed significantly to this study and have read and approved the submitted manuscript. AA-laboratorial experiments, data analysis, figures. MI-laboratorial experiments. YD-SABE coordinators of study teams responsible for

\section{REFERENCES}

1. World Population Ageing 2013. Economic and Social Affairs. New York: United Nations (2013). 111 p. Available from: http://www.un.org/en/development/ desa/population/publications/pdf/ageing/WorldPopulationAgeing2013.pdf (Accessed: July 21, 2016).

2. OECD. Health at a Glance 2015: OECD Indicators. Paris: OECD Publishing (2015). 220 p. doi:10.1787/health_glance-2015-en

3. Passarino G, De Rango F, Montesanto A. Human longevity: genetics or lifestyle? It takes two to tango. Immun Ageing (2016) 13:12. doi:10.1186/ s12979-016-0066-z

4. Sahyoun NR, Lentzner H, Hoyert D, Robinson NK. Trends in causes of death among the elderly. Aging Trends (2001):1-10.

5. Kaplan V, Angus DC, Griffin MF, Clermont G, Scott Watson R, Linde-Zwrible WT. Hospitalized community-acquired pneumonia in the elderly: age- and sex related patterns of care and outcome in the United States. Am J Respir Crit Care Med (2002) 165(6):766-72. doi:10.1164/ajrccm.165.6.2103038

6. Thompson WW, Shay DK, Weintraub E, Brammer L, Cox N, Anderson LJ, et al. Mortality associated with influenza and respiratory syncytial virus in the United States. JAMA (2003) 289:179-86. doi:10.1001/jama.289.2.179

7. Rossi DJ, Bryder D, Seita J, Nussenzweig A, Hoeijmakers J, Weissman IL. Deficiencies in DNA damage repair limit the function of haematopoietic stem cells with age. Nature (2007) 447(7145):725-9. doi:10.1038/nature05862

8. Ju Z, Jiang H, Jaworski M, Rathinam C, Gompf A, Klein C, et al. Telomere dysfunction induces environmental alterations limiting hematopoietic stem cell function and engraftment. Nat Med (2007) 13(6):742-7. doi:10.1038/ nm1578

9. Wagner W, Horn P, Bork S, Ho AD. Aging of hematopoietic stem cell is regulated by the stem cell niche. Exp Gerontol (2008) 43(11):974-80. doi:10.1016/j. exger.2008.04.007

10. Elias HK, Bryder D, Park CY. Molecular mechanisms underlying lineage bias in aging hematopoiesis. Semin Hematol (2017) 54(1):4-11. doi:10.1053/j. seminhematol.2016.11.002

11. Verschoor CP, Johnstone J, Millar J, Dorrington MG, Habibagahi M, Lelic A, et al. Blood CD33(+)HLA-DR(-) myeloid-derived suppressor cells are increased with age and history of cancer. J Leukoc Biol (2013) 93:633-7. doi:10.1189/jlb.0912461

12. Bueno V, Sant'Anna OA, Lord JM. Ageing and myeloid-derived suppressor cells: possible involvement in immunosenescence and age-related disease. Age (Dordr) (2014) 36(6):9729. doi:10.1007/s11357-014-9729-x

13. Strindhall J, Nilsson BO, Löfgren S, Ernerudh J, Pawelec G, Johansson B, et al. No immune risk profile among individuals who reach 100 years of age: findings from Swedish NONA immune longitudinal study. Exp Gerontol (2007) 42(8):753-61. doi:10.1016/j.exger.2007.05.001

14. Palmer DB. The effect of age on thymic function. Front Immunol (2013) 4:316. doi:10.3389/fimmu.2013.00316

15. Dixit VD. Impact of immune-metabolic interaction on age-related thymic demise and T cell senescence. Semin Immunol (2012) 24:321-30. doi:10.1016/j. smim.2012.04.002

16. Surh CD, Sprent J. Homeostasis of naïve and memory T cells. Immunity (2008) 29:848-62. doi:10.1016/j.immuni.2008.11.002

17. Fry TJ, Mackall CL. The many faces of IL-7:from lymphopoiesis to peripheral T cell maintenance. J Immunol (2005) 174:6571-6. doi:10.4049/ jimmunol.174.11.6571 recruitment and sample collection. VB-laboratorial experiments and data analysis, figures, manuscript writing, and primary responsibility for final content.

\section{ACKNOWLEDGMENTS}

To Gianni Saints by statistical analysis, Rosani TS Silva (Central Laboratory-UNIFESP) for the measurement of $\operatorname{IgM}$ and $\operatorname{IgG}$ levels against CMV, FAPESP (Fundação de Amparo à Pesquisa do Estado de São Paulo) financial support (Project 2014/50261-8).

18. Hamman D, Baars PA, Rep MH, Hooibrink B, Kerkhof-Garde SR, Klein MR, et al. Phenotypic and functional separation of memory and effector human CD8+ T cells. J Exp Med (1997) 186(9):1407-18. doi:10.1084/jem.186. 9.1407

19. Hamman D, Konstense S, Wolthers KC, Otto SA, Baars PA, Miedema F, et al. Evidence that human CD8+ CD45RA+CD27- are induced by antigen and evolve through extensive rounds of division. Int Immunol (1999) 11(7):1027-33. doi:10.1093/intimm/11.7.1027

20. Libri V, Azevedo RI, Jackson SE, Di Mitri D, Lachmann R, Fuhrmann S, et al. Cytomegalovirus infection induces the accumulation of short-lived, multifunctional CD4+CD45RA+CD27- T cells: the potential involvement of interleukin-7 in this process. Immunology (2011) 132(3):326-39. doi:10.1111/j.1365-2567.2010.03386.x

21. Di Mitri D, Azevedo RI, Henson SM, Libri V, Riddell NE, Macaulay R, et al. Reversible senescence in human CD4+CD45RA+CD27- memory T cells. J Immunol (2011) 187(5):2093-100. doi:10.4049/jimmunol.1100978

22. Dato S, Crocco P, D’Aquila P, de Rango F, Bellizzi D, Rose G, et al. Exploring the role of genetic variability and lifestyle in oxidative stress for healthy aging and longevity. Int J Mol Sci (2013) 14(8):16443-72. doi:10.3390/ijms140816443

23. Logan SL, Spriet LL. Omega-3 fatty acid supplementation for 12 weeks increases resting and exercise metabolic rate in healthy community-dwelling older females. PLoS One (2015) 10(12):e0144828. doi:10.1371/journal. pone. 0144828

24. Maijó M, Clements SJ, Ivory K, Nicoletti C, Carding SR. Nutrition, diet and immunosenescence. Mech Ageing Dev (2014) 13(6-137):116-28. doi:10.1016/j. mad.2013.12.003

25. Bikle D. Nonclassic actions of vitamin D. J Clin Endocrinol Metab (2009) 94(1):26-34. doi:10.1210/jc.2008-1454

26. MacDonell SO, Miller JC, Harper MJ, Waters DL, Houghton LA. Vitamin $\mathrm{D}$ status and its predictors in New Zealand aged-care residents eligible for a government-funded universal vitamin D supplementation programme. Public Health Nutr (2016) 19(18):3349-60. doi:10.1017/S1368980016001683

27. Moyersoen I. Intake of fat-soluble vitamins in the Belgian population: adequacy and contribution of foods, fortified foods and supplements. Nutrients (2017) 9(8):1-22. doi:10.3390/nu9080860

28. Walker P. Prevalence of vitamin D supplement use in Australian residential aged care facilities in November 2014. BMC Res Notes (2017) 10(1):385. doi:10.1186/s13104-017-2721-7

29. Ginde AA, Blatchford P, Breese K, Zarrabi L, Linnebur SA, Wallace JI, et al. High-dose monthly vitamin $\mathrm{D}$ for prevention of acute respiratory infection in older long-term care residents: a randomized clinical trial. J Am Geriatr Soc (2017) 65(3):496-503. doi:10.1111/jgs.14679

30. Avenell A, Cook JA, Maclennan GS, Macpherson GC. Vitamin D supplementation to prevent infections: a sub-study of a randomised placebo-controlled trial in older people. Age Ageing (2007) 36(5):574-7. doi:10.1093/ageing/ afm091

31. Li-Ng M, Aloia JF, Pollack S, Cunha BA, Mikhail M, Yeh J, et al. A randomized controlled trial of vitamin D3 supplementation for the prevention of symptomatic upper respiratory tract infections. Epidemiol Infect (2009) 137(10):1396-404. doi:10.1017/S0950268809002404

32. Murdoch DR, Slow S, Chambers ST, Jennings LC, Stewart AW, Priest PC, et al. Effect of vitamin D3 supplementation on upper respiratory tract infections in healthy adults: the VIDARIS randomized controlled trial. JAMA (2012) 308(13):1333-9. doi:10.1001/jama.2012.12505 
33. Martineau AR, Hanifa Y, Witt KD, Barnnes NC, Hooper RL, Patel M, et al. Double-blind randomised controlled trial of vitamin D3 supplementation for the prevention of acute respiratory infection in older adults and their carers (ViDiFlu). Thorax (2015) 70(10):953-60. doi:10.1136/thoraxjnl-2015-206996

34. Bergman P, Norlin AC, Hansen S, Björkhem-Bergman L. Vitamin D supplementation to patients with frequent respiratory tract infections: a post hoc analysis of a randomized and placebo-controlled trial. BMC Res Notes (2015) 8:391. doi:10.1186/s13104-015-1504-2

35. Lyons AB, Parish CR. Determination of lymphocyte division by flow cytometry. J Immunol Methods (1994) 171(1):131-7. doi:10.1016/0022-1759(94)90236-4

36. Geginat J, Sallusto F, Lanzavecchia A. Cytokine-driven proliferation and differentiation of human naïve, central memory, and effector memory CD4(+) T cells. J Exp Med (2001) 194(12):1711-9. doi:10.1084/jem.194.12.1711

37. Helmersson-Karlqvist J, Ridefelt P, Lind L, Larsson A. Reference values for 34 frequently used laboratory tests in 80-year-old men and women. Maturitas (2016) 92:97-101. doi:10.1016/j.maturitas.2016.07.015

38. Weinberger B, Lazuardi L, Weiskirchner I, Keller M, Neuner C, Fischer KH, et al. Healthy aging and latent infection with CMV lead to distinct changes in CD8+ and CD4+ T-cell subsets in the elderly. Hum Immunol (2007) 68(2):86-90. doi:10.1016/j.humimm.2006.10.019

39. Van Epps P, Banks R, Aung H, Betts MR, Canaday DH. Age-related differences in polyfunctional T cell responses. Immun Ageing (2014) 11:14. doi:10.1186/1742-4933-11-14

40. Geginat J, Lanzavecchia A, Sallusto F. Proliferation and differentiation potential of human CD8+ memory T-cells subsets in response to antigen or homeostatic cytokines. Blood (2003) 101(11):4260-6. doi:10.1182/blood-2002-11-3577

41. van der Geest KS, Abdulahad WH, Teteloshvili N, Tete SM, Peters JH, Horst G, et al. Low-affinity TCR engagement drives IL-2-dependent post-thymic maintenance of naïve CD4+ T cells in ageing humans. Aging Cell (2015) 14(5):744-53. doi:10.1111/acel.12353

42. Kock S, Larbi A, Derhovanessian E, Ozcelik D, Naumova E, Pawelec G. Multiparameter flow cytometric analysis of CD4 and CD8 T cell subsets in young and old people. Immun Ageing (2008) 5:6. doi:10.1186/1742-4933-5-6

43. Teixeira D, Ishimura ME, Longo-Maugéri IM, Lebrão ML, Duarte YAO, Bueno V. Biological markers changes at the very early stage of ageing (60-65 years). Is there a gender-related effect? Aging Sci (2015) 3:132. doi:10.4172/2329-8847.1000132

44. Goronzy JJ, Fang F, Cavanagh MM, Qi Q, Weyand CM. Naïve T cells maintenance and function in human aging. J Immunol (2015) 194:4073-80. doi:10.4049/jimmunol.1500046

45. Wertheimer AM, Bennett MS, Park B, Uhrlaub JL, Martinez C, Pulko V, et al. Aging and cytomegalovirus (CMV) infection differentially and jointly affect distinct circulating T cell subsets in humans. J Immunol(2014) 192(5):2143-55. doi:10.4049/jimmunol.1301721

46. Jackson SE, Sedikides GX, Okecha G, Poole EL, Sinclair JH, Wills MR. Latent cytomegalovirus (CMV) does not detrimentally alter $\mathrm{T}$ cell responses in healthy old, but increased latent CMV carriage is related to expanded CMVspecific T cells. Front Immunol (2017) 8:733. doi:10.3389/fimmu.2017.00733

47. Wikby A, Maxson P, Olsson J, Johansson B, Ferguson FG. Changes in CD8 and CD4 lymphocyte subsets, T cell proliferation responses and non-survival in the very old: the Swedish longitudinal OCTO-immune study. Mech Ageing Dev (1998) 102(2-3):187-98. doi:10.1016/S0047-6374(97)00151-6

48. Strindhall J, Skog M, Ernerudh J, Bengner M, Löfgren S, Matussek A, et al. The inverted CD4/CD8 ratio and associated parameters in 66-years old individuals: the Swedish HEXA immune study. Age (Dordr) (2013) 35(3):985-91. doi:10.1007/s11357-012-9400-3

49. Arai Y, Martin-Ruiz CM, Takayama M, Abe Y, Takebayashi T, Koyasy S, et al. Inflammation, but not telomere length, predicts successful ageing at extreme old age: a longitudinal study of semi-supercentenarians. EBioMedicine (2015) 2(10):1549-58. doi:10.1016/j.ebiom.2015.07.029

50. Bucci L, Ostan R, Giampieri E, Cevenini E, Pini E, Scurti M, et al. Immune parameters identify Italian centenarians with a longer five-year survival independent of their health and functional status. Exp Gerontol (2014) 54:14-20. doi:10.1016/j.exger.2014.01.023

51. Whisler RL, Beiging L, Chen M. Age-related decreases in IL-2 production by human $\mathrm{T}$ cells are associated with impaired activation of nuclear transcriptional factors AP-1 and NF-AT. Cell Immunol (1996) 169(2):185-95. doi:10.1006/cimm.1996.0109
52. Kaszubowska L. Telomere shortening and ageing of the immune system. J Physiol Pharmacol (2008) 59 Suppl 9:169-86.

53. Sharpless NE, DePinho RA. Telomeres, stem cells, senescence and cancer. J Clin Invest (2004) 113(2):160-8. doi:10.1172/JCI20761

54. Qi Q, Cavanagh MM, Le Saux S, Wagar LE, Mackey S, Hu J, et al. Defective $\mathrm{T}$ memory cell differentiation after varicella zoster vaccination in older in review individuals. PLoS Pathog (2016) 12(10):e1005892. doi:10.1371/journal. ppat. 1005892

55. Shahid Z, Kleppinger A, Gentleman B, Falsey AR, McElhaney JE. Clinical and immunologic predictors of influenza illness among vaccinated older adults. Vaccine (2010) 28:6145-51. doi:10.1016/j.vaccine.2010.07.036

56. Bischoff-FerrariHA, GiovannucciE, WillettWC, Dietrich T, Dawson-HughesB. Estimation of optimal serum concentrations of 25-hydroxyvitamin D for multiple health outcomes. Am J Clin Nutr (2006) 84(1):18-28. doi:10.1093/ ajcn/84.1.18

57. Mithal A, Wahl DA, Bonjour JP, Burckhardt P, Dawson-Hughes B, Eisman JA, et al. Global vitamin D status and determinants of hypovitaminosis D. Osteoporos Int (2009) 20(11):1807-20. doi:10.1007/s00198-009-0954-6

58. Godar DE, Pope SJ, Grant WB, Hokick MF. Solar UV doses of young Americans and vitamin D3 production. Environ Health Perspect (2012) 120(1):139-43. doi:10.1289/ehp.1003195

59. MacLaughlin J, Holick MF. Aging decreases the capacity of human skin to produce vitamin D3. J Clin Invest (1985) 76(4):1536-8. doi:10.1172/JCI112134

60. Gottfried E, Rehli M, Hahn H, Holler E, Andreesen R, Kreutz M. Monocyte derived cells express CYP27A1 and convert vitamin D3 into its active metabolite. Biochem Biophys Res Commun (2006) 349(1):209-13. doi:10.1016/j. bbrc.2006.08.034

61. Wu S, Ren S, Nguyen L, Adams JS, Hewison M. Splice variants of the CYP27b1 gene and the regulation of 1,25-dihydroxyvitamin D3 production. Endocrinology (2007) 148(7):3410-8. doi:10.1210/en.2006-1388

62. Liu PT, Stenger S, Li H, Wenzel L, Tan BH, Krutzik SR, et al. Toll-like receptor triggering of a vitamin D-mediated human antimicrobial response. Science (2006) 311(5768):1770-3. doi:10.1126/science.1123933

63. Wong HJ, Ye XJ, Ng TB. Cathelicidins: peptides with antimicrobial, immunomodulatory, anti-inflammatory, angiogenic, anticancer and procancer activities. Curr Protein Pept Sci (2013) 14(6):504-14. doi:10.2174/13892037 113149990067

64. Lowry MB, Guo C, Borregaard N, Gombart AF. Regulation of the human cathelicidin antimicrobial peptide gene by $1 \alpha, 25$-dihydroxyvitamin D3 in primary immune cells. J Steroid Biochem Mol Biol (2014) 143:183-91. doi:10.1016/j.jsbmb.2014.02.004

65. Olliver M, Spelming L, Hiew J, Meyer-Hoffert U, Henriques-Normark B, Bergman P. Immunomodulatory effects of vitamin D on innate and adaptive immune responses to Streptococcus pneumonia. J Infect Dis (2013) 208(9):1474-81. doi:10.1093/infdis/jit355

66. Rode AKO, Kongsbak M, Hansen MM, Lopez DV, Levring TB, Woetmann A, et al. Vitamin D counteracts Mycobacterium tuberculosis-induced cathelicidin downregulation in dendritic cells and allows Th1 differentiation and IFNy secretion. Front Immunol (2017) 8:656. doi:10.3389/fimmu.2017.00656

67. Le Page A, Garneau H, Dupuis G, Frost EH, Larbi A, Witkowski JM. Differential phenotypes of myeloid-derived suppressor and $\mathrm{T}$ regulatory cells and cytokine levels in amnestic mild cognitive impairment subjects compared to mild Alzheimer diseased patients. Front Immunol (2017) 8:783. doi:10.3389/fimmu.2017.00783

68. Najjar YG, Finke JH. Clinical perspectives on targeting of myeloid derived suppressor cells in the treatment of cancer. Front Oncol (2013) 3:49. doi:10.3389/fonc.2013.00049

69. Lathers DM, Clark JI, Achille NJ, Young MR. Phase 1B study to improve immune responses in head and neck cancer patients using escalating doses of 25-hydroxyvitamin D3. Cancer Immunol Immunother (2015) 53:422-30. doi:10.1007/s00262-003-0459-7

70. Peelen E, Rijkers G, Meerveld-EgginkA, Meijvis S, Vogt M, Cohen Tervaert JW, et al. Relatively high serum vitamin D levels do not impair the antibody response to encapsulated bacteria. Eur J Clin Microbiol Infect Dis (2013) 32(1):61-9. doi:10.1007/s10096-012-1714-7

71. Kriesel JD, Spruance J. Calcitriol (1,25-cihydroxy-vitamin D3) coadministered with influenza vaccine does not enhance humoral immunity in human volunteers. Vaccine (1999) 17(15-16):1883-8. doi:10.1016/S0264-410X(98)00476-9 
72. Heine G, Drozdenki G, Lahl A, Unterwalder N, Mei H, Volk HD, et al. Efficient tetanus toxoid immunization on vitamin D supplementation. Eur J Clin Nutr (2011) 65(3):329-34. doi:10.1038/ejcn.2010.276

73. Khoo AL, Koenen HJPM, Chai LYA, Sweep FCJ, Netea MG, van der Vem AJAM, et al. Seasonal variation in vitamin D3 levels is paralleled by in review changes in the peripheral blood human T cell compartment. PLoS One (2012) 7(1):e29250. doi:10.1371/journal.pone.0029250

74. Saule P, Trauet J, Dutriez V, Lekeux V, Dessaint JP, Labalette M. Accumulation of memory $\mathrm{T}$ cells from childhood to old age: central and effector memory cells in CD4(+) versus effector memory and terminally differentiated memory cells in CD8(+) compartment. Mech Ageing Dev (2006) 127(3):274-81. doi:10.1016/j.mad.2005.11.001

75. Apoil PA, Puissant-Lubrano B, Congy-Jolivet N, Peres M, TkzczukJ, Roubinet F, et al. Influence of age, sex and HCMV-serostatus on blood lymphocyte subpopulations in healthy adults. Cell Immunol (2017) 314:42-53. doi:10.1016/j. cellimm.2017.02.001

76. Liaskou E, Jeffrey L, Chanouas D, Soskic B, Seldin MF, Harper L, et al. Genetic variation at the CD28 locus and its impact on expansion of proinflammatory CD28 negative cells in healthy individuals. Sci Rep (2017) 7(1):7652. doi:10.1038/s41598-017-07967-2

77. Cantorna MT, Snyder L, Lin YD, Yang L. Vitamin D and 1,25(OH)2D regulation of T cells. Nutrients (2015) 7(4):3011-21. doi:10.3390/nu7043011

78. De Vita F, Lauretani F, Bauer J, Bautmans I, Shardell M, Cherubini A, et al. Relationship between vitamin D and inflammatory markers in older individuals. Age (2014) 36:9694. doi:10.1007/s11357-014-9694-4

79. Oliveira C, Biddulph JP, Hirani V, Schneider IJC. Vitamin D and inflammatory markers: cross-sectional analysis using data from the English Longitudinal Study of Ageing (ELSA). J Nutr Sci (2017) 6:e1. doi:10.1017/jns. 2016.37
80. Elizondo-Montemayor L, Castillo EC, Rodriguez-López C, VillarrealCalderón JR, Gómez-Carmona M, Tenorio-Martínez S, et al. Seasonal variation in vitamin $\mathrm{D}$ is association with age, inflammatory cytokines, anthropometric parameters, and life style factors in older adults. Mediators Inflamm (2017) 2017:5719461. doi: 10.1155/2017/5719461

81. Ferrucci L, Corsi A, Lauretani F, Bandinelli S, Bartali B, Taub DD, et al. The origins of age-related proinflammatory state. Blood (2005) 105(6):2294-9. doi:10.1182/blood-2004-07-2599

82. Franceschi C, Bonafè M, Valensin S, Olivieri F, De Luca M, Ottaviani E, et al. Inflamm-aging. An evolutionary perspective on in review immunosenescence. Ann N Y Acad Sci (2000) 908:244-54. doi:10.1111/j.1749-6632.2000.tb06651.x

83. Pradhan AD, Manson JE, Rifai N, Buring JE, Ridker PM. C-reactive protein, interleukin 6, and risk of developing type 2 diabetes mellitus. JAMA (2001) 286:327-34. doi:10.1001/jama.286.3.327

84. Il'yasova D, Colbert LH, Harris AB, Bauer DC, Satterfield S, Kritchevsky SB. Circulating levels of inflammatory markers and cancer risk in the health aging and body composition cohort. Cancer Epidemiol Biomarkers Prev (2005) 14:2413-8. doi:10.1158/1055-9965.EPI-05-0316

Conflict of Interest Statement: The authors declare that the research was conducted in the absence of any commercial or financial relationships that could be construed as a potential conflict of interest.

Copyright (c) 2018 Alves, Ishimura, Duarte and Bueno. This is an open-access article distributed under the terms of the Creative Commons Attribution License (CC BY). The use, distribution or reproduction in other forums is permitted, provided the original author(s) and the copyright owner are credited and that the original publication in this journal is cited, in accordance with accepted academic practice. No use, distribution or reproduction is permitted which does not comply with these terms. 